\title{
Pawel Sopalski
}

Uniwersytet im. Adam Mickiewicza w Poznaniu

\section{Telewizja w kampanii wyborczej - wybrane aspekty}

$\mathrm{K}$ AMPANIA WYBORCZA TO SZCZEGólNY OKREs dla obywateli każdego państwa, ponieważ dysponują wówczas prawem decydowania o tym kto będzie ich reprezentantem. Politycy zaś wykorzystują ten czas po to, aby zabiegać o głosy wyborców. Powstaje pytanie, czy kandydaci są prawdziwi, czy może dbają jedynie o to, aby ich „prawdziwość” była przekonująca?

\section{DEBATY WYBorcZE}

DEBATY WYBORCZE ORGANIZOWANE W CZASIE KAMPANII WYBORCZEJ już dawno zagościły w krajobrazie kampanii wyborczych ${ }^{1}$. Spektakle, z którymi mamy do czynienia obecnie nie są jednak klasycznymi debatami. Brak w nich konfrontacji i czasu na ripostę. We współczesnej debacie trudno o jasne i klarowne stanowisko w konkretnej sprawie, wręcz nieosiągalne wydaje się także widoczne, i co najważniejsze, znaczące zróżnicowanie się postaw widzów wobec konkurencyjnych stron. Obecnie debaty można nazwać co najwyżej „wspólnymi konferencjami prasowymi”" ${ }^{2}$, ponieważ kandydaci biorący w nich udział nie występują naprzeciw siebie, ale odpowiadają na pytania zadane przez dziennikarzy lub nadesłane przez widzów. W ostatnich latach często spotykamy się z debatami między liderami największych partii politycznych. Przed wyborami w 2007 roku odbyła się debata między liderami największych ugrupowań prawicowych: Jarosławem Kaczyńskim (Prawo i Sprawiedliwość) oraz Donaldem Tuskiem (Platforma Obywatelska). Istnieje pogląd, że to właśnie ta debata przedwyborcza zdecydowała o zwycięstwie Platformy Obywatelskiej. W sondażu przeprowadzonym przez Polską Grupę Badawczą w dniach 22-23 września 2007 r. PiS mogło liczyć na $35 \%$ poparcie a PO na $31 \%$. Ta sama grupa przeprowadziła sondaż w dniach 17-19 października 2007 r, a więc już po deba-

${ }^{1}$ W. Cwalina, A. Falkowski, Marketing polityczny. Perspektywa psychologiczna, Gdańsk 2006, s. 353.

${ }^{2}$ Ibidem. 
cie D. Tusk - J. Kaczyński. PO mogła liczyć na 35\% poparcia, Prawo i Sprawiedliwość na 31\%.

Równie ważne w debatach jest to, jak, a nie tylko o czym kandydaci będą rozmawiać. Sztaby wyborcze toczą wielkie boje o to, aby ustalić na jakich zasadach spotkanie ma się odbywać. Często właśnie szczegóły stoją na przeszkodzie przeprowadzenia danej debaty. Możemy zapytać, czy drobne sprawy są tak dużym problemem, czy to może poszczególni kandydaci, a wraz z nimi ich sztaby, boją się, że debata może wywołać odwrotny do zamierzonego skutek i spowodować spadek poparcia?

Do legendy przeszła już debata między Richardem Nixonem oraz Johnem Fitzgerald Kennedy. Była to pierwsza debata telewizyjna zorganizowana w Stanach Zjednoczonych. J. F. Kennedy przybył do Chicago już dzień wcześniej w celu spokojnego przygotowania się do debaty. R. Nixon w „wietrznym mieście” pojawił się dopiero na kilka godzin przed wystąpieniem. Po rozpoczęciu debaty wiceprezydent R. Nixon sprawiał wrażenie zdenerwowanego, co skrzętnie wykorzystał senator J. F. Kennedy. W ciągu pierwszych kilku minut R. Nixon, aż pięciokrotnie przyznał rację swojemu rywalowi. Słowa "Senator Kennedy ma racje...” - nie powinny paść z ust R. Nixona ${ }^{3}$. W opinii widzów lepszy w debacie okazał się J. F. Kennedy i dzięki temu został wybrany na urząd prezydenta.

Nie tylko sama debata przedwyborcza oddziałuje na wyborcę. Po każdym spotkaniu polityków przed kamerami pojawiają się jego medialne sprawozdania w różnego rodzaju mediach. „Koncentrują się one wokół najważniejszych punktów dyskusji i w zasadzie kończą podsumowującą oceną kandydatów, która jest wyrazem opinii dziennikarzy popierających określoną opcję polityczną. Następnego dnia ogłasza się „zwycięzcę” debaty. Niewątpliwie taka sytuacja jest ściśle związana z procesem kampanii w tym ocen dokonywanych przez dziennikarzy, którzy w ten sposób mogą zniekształcić lub całkowicie zmienić sposób postrzegania kandydatów przez ich wyborców"4.

\section{REKLAMA TELEWIZYJNA}

OGŁOSZENIA WYBORCZE EMITOWANE W TELEWIZJI mają przekonać wyborców do tego, że warto na dane ugrupowanie zagłosować. Przyjmując za

${ }^{3}$ Debata Nixon-Kennedy 196o, http://www.marketingwpolityce.zgora.pl/telewizja/debata196o/debata196o.html, o8.11.2011 r.

${ }^{4}$ W. Cwalina, A. Falkowski, Marketing..., op. cit., s. 356. 
kryterium podziału charakter przekazu ogłoszeń wyborczych możemy podzielić je na trzy kategorie: pozytywne, negatywne oraz neutralne.

Filmy o przekazie pozytywnym mają przedstawiać partię lub jej kandydatów w dobrym świetle. Obejrzeć w nich możemy osiągnięcia, którymi stronnictwo może się pochwalić lub też cele, z jakimi do wyborów przystępuje. Głównymi aktorami są wówczas liderzy partii, którzy w otoczeniu wyborców przekonują, że to właśnie głos na nich będzie odpowiednim wyborem. Wszystkiemu towarzyszy zaś spokojna muzyka oraz miłe i przyjazne otoczenie.

Reklama o charakterze negatywnym ma być dla niezdyscyplinowanego elektoratu swego rodzaju straszakiem. Są to krótkie filmy przedstawiające przeciwników politycznych w niekorzystnym świetle. Filmy te składają się z fragmentów przemówień, demonstracji spotkań, które negatywnie rzutują na opinię przeciwników politycznych. Celem takiego nagrania jest przede wszystkim zniechęcenie wyborców do głosowania na daną partię i zmobilizowanie własnego elektoratu do głosowania. Jest to element czarnej propagandy wyborczej.

Spoty o charakterze neutralnym są finansowane zarówno przez partie polityczne, ale także organizacje pozarządowe, które chcą zachęcić obywateli do udziału w wyborach. W dzisiejszych systemach demokratycznych dominuje bowiem niski odsetek obywateli biorący udział w wyborach ${ }^{5}$. W nagraniach zachęcających do działania, np. głosowania, zwykle występują osoby znane, powszechnie doceniane, które nakłaniają widzów do aktywności. Nie są to stricte ogłoszenia wyborcze, jednak większość polityków uznaje je za dobry sposób na uzyskanie lepszego wyniku i większej legitymacji ze strony społeczeństwa. Pragnienie wysokiej frekwencji wyborczej jest jednak często wyrazem hipokryzji. Bowiem w interesie kandydatów, posiadających zdyscyplinowany elektorat, jest to, by frekwencja nie była wysoka. Wzrost frekwencji oznacza zmniejszenie szans wyborczych tym bardziej, gdy dany kandydat (partia) i jego oferta wyborcza dotyczy tzw. medianowego wyborcy ${ }^{6}$.

Nie ulega wątpliwości, że reklama w polityce zmieniła wiele. „Kandydaci do urzędów publicznych uzyskali możliwość kreowania i pro-

5 Frekwencja wyborcza w wyborach parlamentarnych w 2005 roku wyniosła 40,57\%, natomiast w $200753,88 \%$. Najniższa po okresie transformacji frekwencja wyborcza zanotowana została podczas wyborów do Parlamentu Europejskiego. W 2004 r. wyniosła ona zaledwie $20,87 \%$.

${ }^{6}$ P. Pawełczyk, Marketing polityczny $w$ dyktaturze mas, [w:] Problemy wspótczesnej demokracji w ujęciu socjotechnicznym, red. P. Pawełczyk, Poznań 2005, s. 90. 
jekcji swoich wizerunków oraz atakowania wizerunków swoich przeciwników, i to na oczach ogromnej widowni"7. Reklamy kandydatów politycznych realizowane są $\mathrm{w}$ celu podkreślenia pozytywnych lub negatywnych cech kandydata (partii), a ich koszty pochłaniają ponad połowę budżetu typowej kampanii ${ }^{8}$.

Wraz z większym użyciem w czasie kampanii reklamy telewizyjnej, pojawił się wzrost kosztów jej prowadzenia. W roku 1952 koszt kampanii wyborczej na urząd prezydenta w Stanach Zjednoczonych wyniósł 11,6 milionów dolarów. Każda kolejna elekcja pociągała za sobą, coraz większe koszty. Już szesnaście lat później koszty kampanii wzrosły około cztery razy.

W 1988 roku George Bush i Michael Dukakis wspólnie wydali na kampanię wyborczą ponad 80 milionów dolarów. Cztery i osiem lata później budżet George’a Busha, Billa Clintona i Rossa Perota na ten rodzaj komunikacji politycznej zamknął się w granicach 120 milionów dolarów. Natomiast rekordowa suma została wydana w 1992 roku, kiedy Clinton, Ross Perot i Bob Dole zainwestowali blisko 200 milionów dolarów ${ }^{9}$.

W Polsce, inaczej niż w Stanach Zjednoczonych, komitety wyborcze otrzymały prawo do audycji wyborczych w telewizji publicznej. Audycje te odbywają się na koszt telewizji ${ }^{10}$. Wydatki na reklamy telewizyjne, które ponoszone są przez sztaby pokrywają tylko emisję płatnych ogłoszeń wyborczych. Finansowanie kampanii wywołuje w mediach często wiele kontrowersji, ponieważ komitety wyborcze swoją kampanię muszą sfinansować z własnych środków. Każdy obywatel mieszkający na stałe na terenie Polski może wpłacić na dowolny komitet wyborczy sumę nieprzekraczającą 15-krotnego minimalnego wynagrodzenia. Kandydat na posła lub senatora ma możliwość dokonania wpłaty, która nie przekracza 45-krotnego minimalnego wynagrodzenia. Dla ugrupowań nieposiadających reprezentacji w parlamencie finansowanie kampanii wyborczej jest dużym wyzwaniem, ponieważ w przeciwieństwie do stronnictw będących w parlamencie nie posiadają oni dotacji z budżetu państwa. W myśl polskiego prawa (kodeksu wyborczego) wszelkie sprawy związane z finansowaniem kampanii

${ }^{7}$ A. Jabłoński, Marketing polityczny i kampanie wyborcze w USA, [w:] Marketing polityczny w teorii i praktyce, red. A. Jabłoński, L. Sobkowiak, Wrocław 2009, s. 83.

${ }^{8}$ Ibidem, s. 84.

${ }_{9}^{9}$ W. Cwalina, A. Falkowski, Marketing..., op. cit., s. 292.

${ }^{10}$ Dz.U. $2011 \mathrm{Nr} 21$ poz. 112, Art. 117 §1. 
są jawne, a Państwowa Komisja Wyborcza ma za zadanie stwierdzić, czy środki na kampanie zostały pozyskane w prawidłowy sposób.

\section{POLITYK CZY CELEBRYTA?}

NIEODŁĄCZNYMI ELEMENTAMI KAMPANII WYBORCZEJ są wystąpienia telewizyjne. Nie ulega wątpliwości, że w przeciągu ostatnich kilku lat telewizja zmieniła swoje oblicze, stała się nieodłącznym elementem walki politycznej i to nie tylko w czasie kampanii. Rozwój stacji telewizyjnych podyktowany jest wzrastającą popularnością tego medium, ale także rozwojem technologii, który pozwala na pokazywanie wielu wydarzeń na żywo. Rozpowszechnienie środków przekazu, a szczególnie telewizji przyczyniło się także do zmian faktycznych i instytucjonalnych w sposobie sprawowania urzędu przez prezydenta, funkcjonowania rządu, parlamentu i innych organów władzy. Codzienna praca tych ośrodków sprowadza się obecnie do zarządzania informacją, co świadczy o postępującym procesie mediatyzacji rzeczywistości społeczno-politycznej i uległości wobec tego procesu tych instytucji ${ }^{11}$.

Obserwując przez ostatnie kilka lat wydarzenia toczące się na polskiej scenie politycznej zauważamy, że zdecydowana większość wystąpień czołowych polityków transmitowana jest na żywo, a także natychmiast komentowana przez różnego rodzaju ekspertów. Porównując sytuację, która miała miejsce kilkanaście lat wstecz z obecnym stanem rzeczy zauważamy, że obecność polityków nie ogranicza się już do serwisów informacyjnych oraz programów publicystycznych. Politycy przedstawieni są w inny sposób, z którym wcześniej nie mieliśmy do czynienia. Stali się pewnego rodzaju celebrytami, których popularność wynika nie tylko z prezentowanych przez nich poglądów, osiągnięć czy przynależności partyjnej. Społeczeństwo chętnie czyta także o ich życiu prywatnym, które w coraz większym stopniu udostępniane jest przez nich samych dla „dobra” opinii publicznej. Politycy zaczęli pojawiać się także w programach typu talk-show - stali się dosłownie celebrytami.

Proces legitymizacji władzy poszerzył się o potrzebę komunikowania się z wyborcami. Duża część pracy organów władzy ukierunkowana została na komunikację, zarządzanie informacją polityczną, zgodnie z wymogami współczesnych mediów. Wybory nie są już więc jedynym źródłem legitymacji władzy politycznej. Hugues Cazenave twierdzi,

${ }^{11}$ B. Dobek-Ostrowska, R. Wiszniowski, Teoria komunikowania publicznego i politycznego. Wprowadzenie, Wrocław 2001, s. 125. 
że zasadniczą konsekwencją transformacji nowoczesnej sfery publicznej, dokonującej się pod presją mediów, głównie elektronicznych, jest możliwość ciągłej legitymizacji bądź delegitymizacji politycznej, które w epoce przedtelewizyjnej ograniczała się jedynie do wyborów. Czynniki, o których mowa doprowadziły do nowego zjawiska - mediatyzacji polityki ${ }^{12}$.

\section{Podsumowanie}

WALKA WYBORCZA TO TRUDNY OKRES DLA PARTII POLITYCZNYCH, pOnieważ od tego relatywnie krótkiego czasu zależy polityczny los ugrupowania w przyszłości. Brak możliwości realnego wpływania na władzę, czyli w przypadku wyborów parlamentarnych nie przekroczenia progu wyborczego, powoduje marginalizacje stronnictwa na scenie politycznej. Ciężko jest jednak wywierać jakikolwiek nacisk na władze w sytuacji braku zainteresowania ze strony mediów.

Debaty i ogłoszenia wyborcze to dwa ważne czynniki, które wywierają wpływ na decyzje ludzi. Partie w czasie kampanii starają się skoncentrować przede wszystkim na tym, aby trafić do wyborców niezdecydowanych. To ich głosy okazują się bowiem kluczowe. Trudno pogodzić się z faktem, że podobnie jak na rynku konsumpcyjnym tak $\mathrm{w}$ polityce zwyciężają nie najwartościowsze produkty, ale te najlepiej zareklamowane. Teza taka budzi na pierwszy rzut oka oburzenie i sprzeciw, jednak jeśli uznamy, że warunkiem istnienia demokracji jest wolny rynek to czy nie jest konieczne zaakceptowanie mechanizmów rynkowych, które zbliżają nas niestety do wyborów rytualnych, bo na pewno nie racjonalnych. Zdaniem Piotra Pawełczyka i Doroty Piontek obecnie obserwowane przeobrażenia przebiegają wprost proporcjonalnie do wzrastającej roli mediów, przede wszystkim telewi$\mathrm{zji}^{13}$. Czy jednak politycy w pogoni za kreowaniem własnego wizerunku nie odeszli zbyt daleko od polityki? Czy to nie ciężka praca w ławach sejmowych powinny być podstawowym kryterium oceny polityków przez obywateli?

${ }^{12}$ Ibidem, s. 125 .

${ }^{13}$ P. Pawełczyk, D. Piontek, Socjotechnika $w$ komunikowaniu politycznym, Poznań 1999, s. 106. 


\section{Summary}

TElevision has BeCome one of the MOST Significant MEANS of communication during last 50 years. During political campains politicians use a wide range of techniques in order to gain their voters' support. Debates before elections, polls, announcements on Tv are the most common means used by parties. Developement of technology caused the increase of politicians presence not only in the news but also in the shows.

\section{NOTA O AUTORZE}

Pawel Sopalski [pawel.sopalski@gmail.com] - student na Wydziale Nauk Politycznych i Dziennikarstwa oraz na Wydziale Prawa i Administracji Uniwersytetu im. Adama Mickiewicza w Poznaniu. Jego zainteresowania naukowe koncentrują się wokół tematyki związanej $\mathrm{z}$ marketingiem politycznym. 
